AAC 8, 1997, pp. 43-68

\title{
EL CULTO IMPERIAL EN LAS TRES CAPITALES \\ PROVINCIALES HISPANAS: \\ FUENTES PARA SU ESTUDIO Y \\ ESTADO ACTUAL DEL CONOCIMIENTO
}

\author{
José Antonio GARRIGUET MATA \\ Universidad de Córdoba
}

\section{Resumen}

En este artículo efectuamos un análisis comparativo del culto imperial en las tres capitales provinciales de la Hispania romana: Tarraco, Augusta Emerita y Colonia Patricia. Acudimos para ello no sólo a los ya tradicionales testimonios literarios, numismáticos o epigráficos, sino también (y de manera muy especial) a la documentación arqueológica actualmente disponible en dichas ciudades acerca de este importante fenómeno político-religioso del mundo antiguo.

\section{Summary}

In this paper we undertake a comparative analysis on the roman imperial cult in the three provincial capitals of Hispania: Tarraco, Augusta Emerita and Colonia Patricia. We use not only the tradicional literary, numismatic or epigraphic evidence, but also (and specially) the relevant archaeological information from these towns related to this important political and religious phaenomen of the ancient World.

\section{INTRODUCCIÓN}

La investigación sobre el culto imperial romano puede abordarse a través de muy diversas fuentes y desde diferentes puntos de vista. Teniendo en cuenta este hecho, en el presente trabajo hemos intentado establecer, a grandes rasgos, las principales semejanzas y diferencias que, con relación al importante fenómeno del culto imperial, existieron entre las tres ciudades de la Hispania romana que ostentaron el máximo rango político durante los primeros siglos de nuestra Era: Colonia Iulia Urbs Triumphalis Tarraco, capital de la provincia Tarraconense; Colonia Augusta Emeri- 
ta, capital de la Lusitania; y Colonia Patricia Corduba, capital de la Bética. Con vistas a lograr este objetivo hemos optado por ofrecer una visión global y sintética del culto imperial en estas tres capitales, basándonos tanto en los testimonios literarios como en aquellos otros datos aportados por la numismática o la epigrafía. Especial tratamiento tendrá, sin embargo, la cada vez más amplia documentación arqueológica.

Aun cuando el caso de Colonia Patricia -el que más directamente conocemos'presenta ciertas peculiaridades en lo que respecta a este tema, sin embargo, hemos de señalar que el panorama general del culto imperial en dicha ciudad no es tan diferente a los que encontramos en Tarraco o Augusta Emerita como la relativa escasez de evidencias epigráficas $y$, sobre todo, arqueológicas ha hecho pensar tradicionalmente.

\section{LAS FUENTES LITERARIAS}

La existencia en Tarraco de un altar y un templo dedicados ambos a Augusto está atestiguada por Quintiliano, Tácito y los escritores de la Historia Augusta. Quintiliano ha transmitido la anécdota de la palmera que creció milagrosamente encima del altar erigido en honor de Augusto hacia los años 26-25 a.C., es decir, en el contexto de la estancia del Princeps en la capital tarraconense con motivo de las guerras cántabras. Dicho altar fue representado en algunas monedas y ha sido considerado por la mayoría de los investigadores como la primera manifestación del culto imperial de carácter municipal desarrollado en la Tarragona romana (ETIENNE, 1974: 370-375; FISHWICK, 1987: 146 y 176-177):

El templo del Divus Augustus, por su parte, habría comenzado a construirse a partir del año 15 d.C., fecha en la que, en palabras de Tácitot, una embajada de hispanos -supuestamente tarraconenses- obtuvo del emperador Tiberio autorización para llevar a cabo tal proyecto. Este templo, comenta el citado historiador, sirvió de ejemplo para todas las provincias. Según una opinión comúnmente aceptada, con la construcción del mismo se habría instaurado en Tarraco el culto imperial en su nivel provincial (ETIENNE, 1974: 372 y 405-414; FISHWICK, 1987: 154-163), aunque recientes investigaciones han puesto en duda esta afirmación (TED’A, 1989: 167 y 185; RUIZ DE ARBULO, 1993: 98).

' Nuestra Memoria de Licenciatura, leida en la Facultad de Filosofía y Letras de Córdoba a principios de 1997 bajo la dirección de la Profra. Dra. Pilar León Alonso. se titula Testimonios arqueológicos del culto imperial en Colonia Patricia Cordaba y ha sido la base de partida del presente trabajo.

:Inst. Orat. VI. 3. 77.

El primero de estos investigadores sostiene que el altar pudo estar dedicado a Augusıo en soliario, mientras que el segundo defiende una dedicación compartida con la diosa Roma.

Alln. 1. 78. 
Por otro lado, los Scriptores Historiae Augustae aluden en dos ocasiones a la restauración del templo de Augusto en Tarragona. La primera refectio del mismo fue efectuada por Adriano durante su visita a la ciudad en 121-122 d.C.5. La segunda, no del todo segura, podría haber sido ordenada por Septimio Severo tras tener este emperador un sueño profético relativo a dicho edificio".

Frente al caso excepcional de Tarraco, los de Augusta Emerita y Colonia Patricia se encuentran en franca desventaja, ya que ningún escritor de la Antigüedad ha suministrado noticia alguna sobre la presencia en ambas ciudades de monumentos vinculados con el culto al emperador'. Sin embargo, el conocido texto de Tácito" sobre la embajada de la Hispania Ulterior que en el año 25 d.C. pidió permiso a Tiberio para levantar en dicha provincia un templo dedicado a él y a su madre, Livia, y el testimonio directo de Plinio el Joven acerca de los procesos seguidos a finales del siglo I y principios del siglo II d.C. contra dos gobernadores de la Bética a instancias del concilium de ésta (RODRÍGUEZ NEILA, 1978) atañen particularmente a Córdoba: en efecto, debido a su status de capital provincial, Colonia Patricia habría sido la ciudad escogida para emplazar el citado templo, en el supuesto de que éste hubiera llegado alguna vez a erigirse"; por idéntica razón, aunque esta vez con toda certeza, sabemos que Córdoba fue la sede del concilio bético.

\section{LA NUMISMÁTICA}

De especial interés para el conocimiento del culto imperial son las monedas que conmemoraron la erección de monumentos religiosos (templos o altares), al igual que aquellas otras en las que aparecen los principales personajes de la familia imperial, o las que celebran la consecratio, acto mediante el cual los emperadores y emperatrices difuntos que obtenían el permiso oficial del Senado eran declarados divi y divae respectivamente.

A este respecto cabe señalar que si la falta de referencias literarias alusivas al culto imperial en Colonia Patricia puede considerarse un hecho hasta cierto punto normal en el contexto general de la Península Ibérica, no lo es tanto en cambio la au-

Vit. Hadr. XII. 3-5.

"Sel. III. 3.

- No obstante. debemos mencionar el epigrama de Marcial (Ep. IX. 61) dedicado al pláátano plantado en Cordaba por Julio César. que tal vez nos esté indicando la existencia en la capital de la Bética de una particular forma de devoción al primero de los diri a través de dicho árbol sigrado.

Ann. IV. 37.

"La negativa de Tiberio a que se construyera en la Bética un templo consigrado a su persona y a su madre ha sido interpretada de manera distinta por R. Etienne y por D. Fishwick. Para el primero de estos investigadores la razón esencial de tan moderada actitud habria que buscarla en el control efectuado por el Senado sobre dicha provincia. mientras que para el segundo la explicación radicaría en que sólo a los miembros de la familia imperial que hubiesen recibido la consecratio podia rendirsele entonces un culto de carácter provincial (ETIENNE. 1974: 416: FISHWICK. [987: 158). 
sencia de acuñaciones conmemorativas del tipo a las que durante los principados de Augusto y Tiberio se emitieron en Tarraco, Augusta Emerita y otras importantes ciudades hispanas (Cartago Nova, Caesaraugusta, Italica, Hispalis...), donde aparecen representados templos, altares y posibles imágenes de culto imperial o retratos propagandísticos de los principales miembros de la dinastía julioclaudia en aquellos instantes.

En efecto, algunas monedas emitidas por Tarraco en época tiberiana ( $R P C \mathrm{I}$, 218-219, 221-222, 224-226 y 231) muestran en sus reversos un altar decorado con bucráneos, guirnalda de hojas de roble y escudo, y un templo octástilo que estuvo consagrado al Divus Augustus (aunque junto a él aparece la leyenda Aeternitatis Augustae). En los anversos están representados Augusto como Deo o Divus y el emperador Tiberio. Pero debemos recordar también aquellas otras acuñaciones tarraconenses, tanto augusteas como tiberianas, en las que aparecen las efigies de Augusto como Imperator y como Divis, sus nietos Cayo y Lucio, Tiberio, Druso, Germánico y lulia Augusta (RPC I, 210-213, 215, 228-230, 232 y 233), pues constituyen un claro ejemplo de propaganda dinástica.

No obstante, pese a que los testimonios numismáticos -y también los literariosdemuestran la existencia en la Tarragona de principios del siglo I d.C. de un altar y un templo dedicados a Augusto, hasta el momento no se ha hallado en la ciudad ningún vestigio de cualquiera de estos dos monumentos tan vinculados con el culto al emperador "'. En la actualidad se piensa que ambas construcciones se ubicaron en el entorno del Foro bajo o colonial, habiéndose descartado por completo (al menos para el altar) su emplazamiento en la parte alta de la ciudad (FISHWICK, 1987: 171 179; 1996: 172-174; RUIZ DE ARBULO, 1990: 125; 1993: 94-95).

En Mérida se acuñaron también durante el principado de Tiberio algunas series de monedas con la cabeza del Divus Augustus o la del propio emperador en los anversos y un altar y un templo tetrástilo, acompañados de las leyendas Providentia y Aeternitati Augustae respectivamente, en sus reversos (RPC I, 28-29, 34-36, 45-48). Augusta Emerita, como hiciera Tarraco, también emitió monedas con la efigie de Iulia Augusta (RPC I, 38-40). En opinión de R. Etienne (1974: 378-379) el altar de Mérida dedicado a la Providencia se habría erigido hacia el año 15 a.C., conectándose con el origen del culto municipal. Sin embargo, la supuesta falta de restos epigráficos o arqueológicos del mismo y la semejanza tipológica que mantiene con el altar de la Providentia levantado en Roma por Tiberio en torno al 29 d.C. -cuya imagen aparece en monedas de la Urbs- han llevado a D. Fishwick (1987: 180-184) a afirmar que las monedas emeritenses conmemoraron en realidad la erección del altar ti-

" Una inscripción con las palabras Divo Augusto. aparecida en un sector de la ciudad situado aproximadamente a medio camino entre el circo y el anfiteatro y perdida desde hace tiempo (ALFÖLDY. 1975: 34) ha sido considerada por Etienne (1974: 408), como perteneciente al templo. opinión que. sin embargo. no comparte Fishwick (I987: 153). 
beriano consagrado a la Providentia en la capital del Imperio" ${ }^{11}$ Un razonamiento similar sigue Fishwick para el altar que aparece en ciertas emisiones de Italica con la leyenda Providentiae Augusti en su interior (RPC I, 64-65), pese a las variantes tipológicas que presenta con relación a los de Roma y Mérida.

Etienne y Fishwick coinciden, en cambio, en considerar al templo tetrástilo de las monedas de Mérida como el punto de partida del culto provincial en Lusitania, centrado en el Divus Augustus a semejanza de lo que habría ocurrido tan sólo algunos años antes en Tarraco (ETIENNE, 1974: 414-415; FISHWICK, 1987: 156-157). Para algunos autores, los monumentales restos exhumados en los n. ${ }^{\circ}$ s5-37 de la calle Holguín podrían corresponder a este templo (ÁLVAREZ, 1991b: 21; BARRERA, 1994: 443-459; CERRILLO, 1995: 67).

Por otro lado, un anaglyphum de plata hallado en Mérida y conservado en la Real Academia de la Historia podría indicar la presencia en dicha ciudad de un templo dedicado a Antonino Pío tras su divinización. En él se observa, efectivamente, un templo hexástilo (o una edícula) en cuyo arquitrabe se leen las palabras Divo Antonino Pio Aug. (CIL II, 480). Basándose en la existencia de seis columnas en su fachada, Fishwick (1987: 183) ha relacionado este monumento con el llamado «templo de Diana», hipótesis que, sin embargo, ya había desestimado A. Blanco (1982: 30) y que en fechas más recientes ha sido también rechazada por J.M." Alvarez (1991a: 92) o J.L. de la Barrera (1994: 487-488)

En claro contraste, por tanto, con las situaciones de Tarragona y Mérida que acabamos de exponer, la únicas monedas acuñadas con seguridad por la ceca de Córdoba durante la época imperial -fechadas en torno a los años 13-11 a.C., esto es, en pleno principado de Augusto- muestran en sus anversos la cabeza del Princeps a la izquierda, mientras que en sus reversos se alternan la corona de laurel, insignias militares e instrumentos sacerdotales (CHAVES, 1977: 89-122). Dichas monedas reflejan en cierto modo el agradecimiento y la lealtad de la ciudad hacia Augusto, quien llevó a cabo en ella una deductio de soldados veteranos y, quizás, le otorgó el estatuto de colonia Civium Romanorum (VENTURA, 1996: 140-142). Pero no encontramos en ellas ningún rastro de posibles monumentos cordobeses vinculados con el culto al emperador, ni efigies de los personajes asociados al trono imperial. Y tampoco se tiene constancia de emisiones tiberianas que pudieran reflejarlos ${ }^{2}$.

"J. L. de la Barrera (1994: 459-463) considera igualmente que las monedas acunadas en Roma con la representación del altar de la Providentia sirvieron como modelo para las citadas emisiones emeritenses. No obstante. y a diferencia de lo que piensa Fishwick. Barrera defiende la existencia real del altar de Mérida. emplazándolo en el llamado Foro provincial y datando su construcción en los últimos años del principado de Tiberio. En fechas más recientes T. Nogales (e.p.) ha defendido la pertenencia de los relieves de Pancaliente-donde aparece Agripa. patrono de la ciudad. ofreciendo un sacrificio- a ese altar de la Providencia que muestran las monedas emeritenses. Para esta investigadora. dicho altar debió localizarse, sin embargo. en el ámbito del Foro municipal.

': Esta situación podría verse en parte modificada si se confirmaran las investigaciones que M. Ángel Cebrián -compañero nuestro en el Seminario de Arqueología de la Universidad de Córdoba- ha realizado en el marco de su 
La reducida actividad de la ceca de Córdoba a comienzos de la etapa imperial podría explicarse en gran medida por la escasa tradición acuñadora de la ciudad, que durante toda la época republicana sólo había emitido (hacia los años 80-79 a.C.) algunas series de monedas con leyenda Corduba y las imágenes de Venus y Cupido (CHAVES, 1977: 43-88). Además, su papel de capital de la Bética habría garantizado el abastecimiento de abundante numerario acunado en otras ciudades de la provincia. Pero teniendo en cuenta el notable valor que Tarraco, Augusta Emerita y otras ciudades peninsulares otorgaron en época augustea y tiberiana a las monedas como medio para expresar su adhesión al nuevo régimen político y a la familia gobernante, y para conmemorar la construcción en sus respectivos solares de recintos cultuales dedicados al Divus Augustus -entrando incluso en abierta competencia entre ellas por esta causa ${ }^{13}$-, resulta difícil entender por qué razón Colonia Patricia no recurrió, al parecer, al eficaz sistema de la amonedación para dar publicidad de estos eventos.

\section{LA DOCUMENTACIÓN EPIGRÁFICA}

Los epígrafes constituyen, por lo general, los testimonios más claros y fehacientes de la existencia de culto imperial en un lugar y un momento concretos. En ocasiones informan de la construcción de un templo o de cualquier otra edificación sacra destinada a esta faceta del culto oficial (ORIA y MORA DE LOS REYES, 19911992: 124-128). Pero la mayoría de las veces se trata de dedicaciones al emperador vivo o ya divinizado, a su genius o numen, a la emperatriz u otros miembros de su familia, a magistrados y otros cargos religiosos municipales o provinciales (flamines, flaminicas, pontifices, seviri augustales, magistri Larum...) encargados del culto, a las denominadas divinidades augustas y a las virtudes imperiales.

De las tres ciudades analizadas Tarragona es la que mayor cantidad y variedad de inscripciones relacionadas con el culto imperial ha proporcionado. Así, en el llamado Foro bajo y en su entorno, localizado entre las actuales calles Soler y Gasómetro y sus proximidades, han aparecido casi todos los epígrafes que pueden relacionarse con el culto local, comprendiendo éstos tanto dedicaciones a los emperadores o a miembros de sus familias (ordenadas cronológicamente desde el principado de Tiberio hasta el período de la Tetrarquía, con importantes ejemplos en época an-

\footnotetext{
Memoria de Licenciatura, titulada La tipologia de las monedas y la fundación de la Colonia Patricia. donde se establecen cuatro momentos de acuñación para la ceca cordobesa: los dos primeros en época de las Guerras Civiles y los dos segundos ya durante el principado de Augusto.

En los primeros instantes del culto imperial las ciudades y provincias del Imperio Romano rivalizaron entre ellas por demostrar su fervor y devoción hacia Augusto y su familia mediante la erección de monumentos. la dedicación de epigrafes y estatuas o. precisamente. la emisión de monedas (ZANKER. 1992: 343-382). Este último aspecto ha sido tratado por J. Gimeno (1994: 60-68) en relación a la «disputa» que mantuvieron Tarraco y Cartago Nosa por obtener la ansiada capitalidad de la provincia Tarraconense.
} 
tonina), como a las divinidades y virtudes augustas o a las personas encargadas de la celebración y el mantenimiento del culto: flamines y flaminicas, seviri augustales y/o magistri Larum (ALFÖLDY, 1975; RUIZ DE ARBULO, 1990: 128-138; 1993: 9495). La cronología de las inscripciones dedicadas a esos cargos religiosos municipales se sitúa entre comienzos de la época julioclaudia y, aproximadamente, mediados del siglo II d.C. para flamines y flaminicas, y entre principios del siglo I d.C. y el primer tercio del siglo III d.C. para los seviri augustales y los magistri Larum.

Por su parte, la mayoría del casi centenar de inscripciones dedicadas a los flamines y flaminicas de la provincia Tarraconense (ALFÖLDY, 1973; 1975: 91-95 y 137180) ha sido localizada en el solar que ocupara la gran plaza de representación de la terraza superior de Tarraco o en sus inmediaciones. Dichos epígrafes se fechan entre los años 70 y 170-180 d.C. (ALFÖLDY, 1973: 14-19). La titulación más frecuente de estos sacerdotes es la de flamen/flaminicae provinciae Hispaniae citerioris, aunque en algunos casos se especifica el título oficial completo: flamen Romae Divorum et Augustorum provinciae Hispaniae citerioris (ALFÖLDY, 1973: 46-49). En esta zona han aparecido también algunas dedicaciones imperiales, cuya cronología abarca desde la época flavia hasta bien entrado el siglo V d.C., aun cuando la mayor concentración de las mismas se produce entre los siglos II y III d.C. (ALFÖLDY, 1975: 37-57). Por su parte, en el sector del teatro debemos destacar la aparición de un interesante altar dedicado al numen Augusti y fechado en época augustea (ALFÖLDY, 1975: 27).

En Mérida no son demasiados los epígrafes relacionados con el culto imperial que se conocen hasta el momento, aunque su número se ha incrementado algo en los últimos años. Así, en el ámbito del Foro de la colonia han aparecido la inscripción del flamen Augusti P. Attennius Afer (BARRERA, 1994: 470) y dos pedestales imperiales del siglo III d.C. (SAQUETE y MÁRQUEZ, 1997). Sin embargo, en el «Foro de mármol» descubierto en la calle Sagasta o en el llamado Foro provincial, ubicado en la zona del Parador de Turismo, no se han localizado epígrafes correspondiente a flamines o a cualquier otro cargo religioso de la ciudad o la provincia. En el segundo de estos espacios forenses cabe destacar, sin embargo, la presencia de dedicaciones a la Concordia Augusti y a los emperadores Tiberio, Domiciano, Trajano y Constantino (ÁLVAREZ, 1982: 63-64; 1991b: 20-21; BARRERA, 1994: 449-452).

En el ámbito del teatro emeritense debemos mencionar, por un lado, las inscripciones de dos flamines coloniales halladas en el pórtico post scaenam. Una de ellas corresponde al pedestal de estatua de Cn. Cornelio Severo, flamen de Iulia Augusta, fechado, por tanto, en época tiberiana'^ (TRILLMICH, 1993a: 119-121); por otro, seis pequeños pedestales de estatua elaborados en mármol y con la inscripción

${ }^{14} \mathrm{Al}$ igual que los primeros flamines municipales conocidos en otras ciudades de la Lusitania como Pax lulia. Olisipo o Salacia (ETIENNE. 1990: 222). 
Aug(usto) Sacr(um) en sus caras frontales, procedentes del sacrarium de culto imperial construido en época trajanea en el sector central de la imma cavea (TRILLMICH, 1989-1990: 98-100; 1993b: 116-117).

En zonas de la ciudad diferentes a las ya enumeradas o bien en contextos desconocidos se han descubierto las inscripciones de Modestus, flamen divi Augusti, Valeria Viniciana, flaminica perpetua, así como las de varios augustales y seviri augustales, uno de los cuales se fecharía a comienzos de la dinastía julioclaudia (BARRERA, 1994: 471, nota 75). Curiosamente, ni en Mérida, ni en ninguna otra ciudad de Lusitania se ha documentado epígrafe alguno dedicado a los magistri Larum (ETIENNE, 1974: 282). Entre los flamines provinciales, el más antiguo por el momento es Albinus, que fue Divi Augusti et Divae Augusta en época de Claudio, cronología similar a la que poseen los primeros sacerdotes de la provincia atestiguados en otras ciudades lusitanas (ETIENNE: 1990: 220-222). Por el contrario C. Pompeyo Prisco, flamen de la colonia y la provincia en la primera mitad del siglo II d.C., es el más moderno (ETIENNE, 1990: 220). Finalmente, una Helvia, fue flaminica provincial en época flavia o antonina (VELÁZQUEZ, 1988).

Los Foros de las calles Cruz Conde-Góngora y Ángel de Saavedra y sus respectivos entornos concentran la mayor parte de los epígrafes relacionados con el culto imperial que actualmente se conocen en Córdoba. En el primero de ellos, designado también con el nombre de Foro colonial, se han hallado varios pedestales imperiales de los siglos III y IV d.C. con la habitual fórmula devotus/a numini maiestatique eius/a $(D N M Q E)$ inscrita al final del texto ${ }^{15}$. También se han descubierto en este Foro las basas de estatua dedicadas a los flamines provinciales L.? Julio Gallo Mummiano (CIL II $=/ 7,282)$, L. Cominio Juliano (CIL II $=/ 7,293)$, M. Helvio Rufo (CIL II $/ 7,296$ ) y L. Licinio Montano Sarapio (APARICIO y VENTURA, 1996), a los cuales hemos de unir el nombre de L. Valerio Fuscino, citado en la inscripción de Filipo el Árabe (CIL II $=/ 7,255)^{16}$. Cronológicamente, estos flamines Divorum Augustorum provinciae Baeticae se sitúan entre finales del siglo I y los comedios del siglo III d.C.

En el Foro de la calle Ángel de Saavedra (o Foro de Altos de Santa Ana) han aparecido de momento una inscripción imperial, la de Filipo II $(C I L I I=/ 7,256)$, la basa erigida en honor de Fulcinia Prisca, flaminica municipal del siglo II d.C. (CIL II $/ 7$, $305)$ y varios pedestales de estatua de flamines provinciales -los de C. Antonio Serano (CIL II $/ 77,291)$, Clodio Saturnino (CIL II $=/ 7,292)$, L. Octavio Liciniano (CIL II'/7, 297) y Fabio ...do (CIL II'/7, 295)- fechados entre finales del siglo II y el primer cuarto del siglo III d.C.

'Se trata de los dedicados a Filipo el Árabe (CIL II $/ 7.255)$. Galieno y Valeriano (CIL II $/ 7$. 257). Cornelia SaIonina ( $C I L$ II $/ 77.258)$. Constancio Cloro ( $C I L$ II $/ 7$. 26I) y Constantino II ( $C I L$ II $/ 7$. 264).

"No es esta la única inscripción imperial de Córdoba en la que figura el nombre de un flamen provincial como sistema de datación. pues en un pedestal de procedencia desconocida y dedicado a dos augustos de mediados del siglo III d.C. (probablemente Valeriano y Galieno) se menciona al flamen M. Valerio Saturnino (CIL II:/7. 259). 
Muy interesante resulta a su vez la inscripción Augusto Sacrum $(C I L$ II/7, 253) grabada en una columna marmórea y hallada en la calle Amparo (cerca ya de la muralla Sur de la ciudad), pues la misma pudo estar situada originalmente en el teatro cordobés (VENTURA, 1996: 164) como aconteció en el teatro de Mérida con los pedestales del sacrarium trajaneo que portan similar dedicación (TRILLMICH, 19891990: 98-100; 1993b: 116-117). No obstante, la pieza de Córdoba posee una cronología tardoaugustea. Asimismo, en el solar que hoy día ocupa el Colegio de Santa Victoria, -esto es, donde se habría ubicado la terraza más elevada de las tres conectadas con el teatro (VENTURA, 1996: 154)- se hallaron en 1761 varios epígrafes fragmentados de carácter honorífico, dos de los cuales pudieron corresponder a una sacerdotisa y a un flamen provincial respectivamente (CIL II $/ 77,298,299$ y 376).

Fuera de los espacios reseñados han aparecido, además de ciertos pedestales imperiales de los siglos III y IV d.C. (CIL II $=/ 7,260,262,263,265$ y 266), las inscripciones de C. Cosano Rustico, flamen designatus provinciae Baeticae a principios del siglo II d.C. (CIL II $/ 7,294)$; dos hermanos que desempeñaron con éxito el flaminado colonial en el siglo II d.C. (CIL II $/ 7,237)$; una posible flaminica local de esa misma centuria (CIL II $/ 7,310)$; y la basa para una estatua de Colonia Patricia dedicada por L. Junio Paulino, flamen colonial y provincial e importante evergeta cordobés en época de los Severos $(C I L I I / 7,221)$. Finalmente, los diversos epígrafes de seviri augustales y magistri Larum recordados en Córdoba (CIL II $=/ 7$, 240, 322-329 y 331) poseen en casi todos los casos un carácter funerario y se fechan entre la época julioclaudia y los primeros años del siglo III d.C.

\section{LA DOCUMENTACIÓN ARQUEOLÓGICA}

Nuestra atención se dirige, por último, hacia aquellos espacios y edificios públicos de las tres capitales hispanas que, en función de sus elementos de decoración arquitectónica o escultórica, y/o de los testimonios epigráficos, mantuvieron una estrecha relación con el culto y la propaganda imperiales.

Comenzamos de nuevo exponiendo el caso de Tarraco, en cuyo Foro bajo se construyó en época augustea una basílica jurídica dotada de un aedes Augusti, sala de culto imperial utilizada como Tribunal que estuvo pavimentada con losas de mármol y presidida por una imagen del emperador (MAR y RUIZ DE ARBULO, 1987; 1988: 283-284; FISHWICK, 1996: 167-172). A este mismo ámbito forense se adscriben dos ciclos icónicos imperiales: uno julioclaudio, ubicado en la mencionada basílica y en el que sobresalen una cabeza masculina velada (posiblemente Augusto) y un torso femenino (¿Livia?); y otro antonino, en el cual se incluyen las cabezas-retratos de los emperadores Marco Aurelio y Lucio Vero (KOPPEL, 1985: 32-51). En un solar adyacente a este Foro se descubrieron en 1995 sendos retratos de Tiberio y Nerón Germánico, fechados en el segundo cuarto del siglo I d.C. Es posible que am- 
bos se localizasen originalmente en la basílica, como el resto de las imágenes que componen el ciclo julioclaudio (KOPPEL, e.p.; KOPPEL y MACÍAS, 1995). Del Foro bajo procede, asimismo, una curiosa campana con inscripción que debió emplearse en los rituales del culto oficial. Su cronología es probablemente antonina (ALFÖLDY, 1975: 200-201; RUIZ DE ARBULO, 1990: 133).

Junto al flanco oriental del Foro colonial se ubicó el teatro de Tarraco, cuya fecha exacta de construcción resulta contradictoria, pues aunque las estratigrafías obtenidas en las excavaciones apuntan hacia una cronología flavia, sin embargo, el estilo de los capiteles más antiguos y el hallazgo de un ciclo estatuario imperial -datado por E. Koppel (1985: 13-32) entre los principados de Tiberio y Claudio y procedente a todas luces de la scaenae frons del edificio-, así como del altar augusteo dedicado al Numen Augusti, han llevado a pensar que las obras del mismo pudieron iniciarse en un momento bastante anterior (MAR, ROCA y RUIZ DE ARBULO, 1993). Sea como fuere, en pleno siglo II d.C. el teatro tarraconense conoció un intenso proceso de restauración y marmorización completado mediante la colocación en su scaena frons de varias esculturas thoracatas de la dinastía antonina (KOPPEL, 1985: 13-32). Sin embargo, estas reformas tuvieron una breve vigencia, pues a finales de la citada centuria el teatro fue abandonado, perdiendo su función de espacio público (MAR, ROCA y RUIZ DE ARBULO, 1993: 18). En cuanto al anfiteatro, éste fue construido extramuros de la ciudad en la primera mitad del siglo II d.C. y a expensas de un flamen provinciae (RUIZ DE ARBULO, 1993: 100-101, 109 y 111).

En los primeros años del principado de Vespasiano comenzó en Tarraco la construcción de un impresionante complejo arquitectónico destinado a acoger la sede y las ceremonias del concilium provinciae. El lugar escogido fue la zona alta de la ciudad, hasta entonces ocupada parcialmente por viejas estructuras militares (RUIZ DE ARBULO, 1993: 94 y 98). Este proceso de monumentalización supuso la creación de un amplio espacio de composición axial estructurado en distintos niveles y ocupado, en sentido descendente, por un recinto de culto imperial-que albergaría en su interior un templo ${ }^{17}-$, una enorme plaza de representación porticada y un circo.

Según los datos estratigráficos el recinto de culto superior y la plaza de representación se erigieron hacia los años 69-70 d.C." nología posterior, domicianea (TED’A, 1989: 160 y 181; MAR, 1993: 111-113). En

\footnotetext{
1- Se ha pensado que dicho templo pudo haber sido el mismo que conocemos a través del texto de Tácito y de las monedas tiberianas. aunque ello implicaría que su construcción se habria dilatado más de medio siglo. dada la cronología flavia del complejo provincial (TED’A. 1989: 156-157). Ruiz de Arbulo (1990: 132: 1993: 94-95) opina, sin embargo. que el templo mencionado por Tácito debió emplazarse en el Foro de la colonia y no en la terraza superior. Sea como fuere. debido a su disposición con respecto al recinto de culto que lo rodea. este edificio religioso tiene como principales paralelos el aedes del Templam Pacis de Vespasiano en Roma o el templo del santuario imperial de "Cigognier". en Aienticum (TED'A, 1989: 155; MAR. 1993: 120-129).

"En contra de esta opinión se ha expresado D. Fishwick (1996: 178-182), quien considera que el recinto de culto habría sido construido en época julioclaudia (esto es, antes que la plaza de representación). e identifica dicho recinto con el templo al que aluden Tácito y las monedas tarraconenses.
} 
la decoración arquitectónica del recinto de culto, elaborada en mármol de Luni, se imitó en parte el programa ornamental del Foro de Augusto en Roma, como demuestran los fragmentos de clípeos con cabezas de Júpiter Amón y Medusa que debieron localizarse en el ático de los pórticos (PENSABENE, 1993: 89-97). Pero aquí los clipei no se alternaron con cariátides como en el Forum Augusti de Roma, sino con pilastras de candelabros vegetales (TED'A, 1989: 164-167; MAR, 1993: 138151). Pese a esta variación, la presencia de clípeos, relieves con bucráneos, guirnaldas e instrumentos sacerdotales y frisos de roleos vegetales ha sido considerada una prueba más de la conexión de este espacio sagrado con el culto imperial (TED'A, 1989: 162-167; MAR, 1993: 133-140).

En referencia a la gran plaza de representación intermedia (TED'A, 1989; GÜELL et alli, 1993), todo este gran complejo monumental ha sido designado en la literatura científica con el nombre de Foro "provincial»" ${ }^{19}$, fundamentalmente por haberse descubierto en la citada plaza la práctica totalidad de los pedestales dedicados a los flamines, flaminicas y altos funcionarios de la Tarraconense. Esta circunstancia ha sido utilizada como argumento para establecer una distinción tajante entre el mencionado Foro provincial, administrado férreamente por el concilium, y el espacio forense sometido a las decisiones del ordo decurionum, el denominado Foro bajo" ${ }^{20}$.

Por lo que respecta a Mérida, entre los edificios de culto imperial conocidos hasta la fecha en esta ciudad merece destacarse en primer lugar el llamado «templo de Diana». Dicho templo, períptero y hexástilo, presidió el Foro «municipal» (ÁLVAREZ, 1991a: 85; 1991b: 17-18) o «central» (TRILLMICH, 1995: 269; 1996a: 175), ubicado aproximadamente entre las actuales calles Berzocana, Romero Leal y Ávalos. La dedicación de este templo al culto imperial se infiere de las características topográficas y constructivas (ÁLVAREZ, 1991a: 92-93) y de los hallazgos escultóricos acaecidos en su interior o en el entorno inmediato: dos torsos masculinos sedentes (correspondientes a sendas estatuas de emperadores heroizados), una figura femenina estante y dos retratos femeninos, uno de los cuales ha sido identificado como Antonia minor (NOGALES, 1989-1990 y 1996). El material empleado en su construcción -granito estucado- y el estilo de sus capiteles demuestran que la cronología del «templo de Diana» -como la del Foro que domina- es plenamente augustea (BARRERA, 1994: 475). Recientemente, T. Nogales (e.p.) ha defendido la posible pertenencia a este mismo ámbito forense de los relieves de Pancaliente en los que aparece representado el patrono de la ciudad, Marco Vipsanio Agripa, en el momento de efectuar un sacrificio. Dicha escena pudo pertenecer, según Nogales, al altar de la Providencia presente en ciertas monedas emeritenses.

1" No obstante. en alguna ocasión se ha propuesto también denominarlo Augusteum (GIMENO. 1994: 68-71).

$\therefore$ Totalmente contrario a esas denominaciones modernas se ha manifestado. sin embargo. W. Trillmich (1993a y 1996a: 181-183) 
Enorme interés poseen también los restos monumentales hallados en los números 11-13 de la calle Sagasta, interpretados por W. Trillmich (1995: 276-277) como correspondientes a una plaza distinta al Foro de la colonia pero adosada a él -un Forum adiectum a la manera de los Foros imperiales de Roma- y construida en época claudio-neroniana, según se deduce del análisis de su decoración escultórica y arquitectónica (TRILLMICH, 1995, 1996a y 1996b; BARRERA y TRILLMICH, 1996)"'. Esta nueva plaza de Augusta Emerita ha sido designada por Trillmich (1995) con el nombre de Foro de «mármol», en alusión al destacado papel que desempeñó este material en su ornamentación y para distinguirla del Foro «central», cuyo «templo de Diana» fue edificado como sabemos con granito revestido de estuco. La presencia en el ático del pórtico hallado en la calle Sagasta de clípeos con cabezas de Júpiter Amón y Medusa separados por cariátides (ÁLVAREZ y NOGALES, 1990) refleja claramente la influencia ejercida por el Forum Augustum de Roma sobre esta plaza emeritense, influjo materializado también a través de la epigrafía (BARRERA y TRILLMICH, 1996: 128-136) y la decoración escultórica, ya que los nichos existentes en la fachada interior del espacio porticado albergaron una galeria de efigies togadas que representan a hombres ilustres de la etapa republicana, los summi viri, y a los reyes míticos de Roma. A ellos hay que unir el grupo estatuario constituido por la imagen colosal del héroe troyano Eneas con su padre, Anquises, y su hijo, Ascanio (TRILLMICH, 1995: 278-289; 1996b; BARRERA y TRILLMICH, 1996: 119128).

Por otra parte, diversos elementos arquitectónicos aparecidos en el solar número 9 de la calle Baños, es decir, junto al supuesto lado meridional del «Foro de mármol», podrían corresponder a una exedra o estancia destinada al culto contigua a dicho flanco (TRILLMICH, 1995: 277-278; 1996a: 180-181). La falta de testimonios epigráficos determinantes"- impide saber de momento a quién o a qué estuvo consagrada esta sala y qué institución se encargó de su cuidado y administración (TRILLMICH, 1996a: 182-183). Sobre estas cuestiones poco podemos aportar ahora, salvo recordar la conexión que existió entre el tema decorativo de los clipei con cabezas de Júpiter Amón y Medusa con el fenómeno del culto y la propaganda imperiales (TED'A, 1989: 162-167; ETIENNE, 1990: 218; MAR, 1993: 133-140).

Con respecto al teatro de Augusta Emerita, las inscripciones situadas en los dinteles de los parodoi fechan su construcción entre los años 16-15 a.C. y a instancias

\footnotetext{
: Sin embargo. en opinión de J.M Álvarez y T. Nogales (1990: 337) este espacio porticado constituiría un sector anexo al Foro colonial augusteo e integrado en el mismo, de ahí el nombre de «Pórtico del Foro" empleado por dichos autores para referirse a estas estructuras. A juicio también de Álvarez y Nogales. en su construcción podrían distinguirse dos fases cronológicas, una julioclaudia. con una arquitectura realizada a base de granito. y otra flavia. caracterizada por el empleo masivo de elementos marmóreos.

"- Hasta la fecha no ha parecido aquí ningún epígrafe que permita emitir alguna hipótesis al respecto, ni siquiera el de algún flamen de la colonia o la provincia. En relación con los flamines esta circunstancia es prácticamente común a las otras dos plazas de Augusta Emerita (TRILLMICH, 1993a: 120: 1996a: 182-183).
} 
de Agripa, aunque no todo el edificio se adscribe a la época augustea ${ }^{33}$. A esta primera fase constructiva pertenecen, por ejemplo, la ima cavea y la orchestra, además de la pequeña sala cuadrangular ubicada en el portico post scaenam. De dicha estancia (pavimentada y revestida en su interior con losas de mármol, y dotada de cinco nichos) proceden cinco estatuas togadas y tres cabezas imperiales: las de Tiberio y Druso, que encajan perfectamente en dos de los togados, y la de Augusto, mayor que las otras y velada (ÁLVAREZ SÁENZ DE BURUAGA, 1982: 310; BOSCHUNG, 1990: 391-395; GROS, 1990: 386-387; TRILLMICH, 1993b: 113-114; CERRILLO, 1995: 65-66). En esta sala se halló igualmente la inscripción de un flamen consagrado al culto en vida de Iulia Augusta (TRILLMICH, 1993a: 119-121). En un primer momento se pensó que tal estancia fue utilizada como biblioteca, pero en la actualidad la mayoría de los investigadores se inclina a considerarla un sacellum de culto imperial (ÁLVAREZ SÁENZ DE BURUAGA, 1982: 310; BOSCHUNG, 1990: 391-395; GROS, 1990: 386-387; CERRILLO, 1995: 65-66). No obstante, Trillmich (1993b: 114) discrepa totalmente de esta interpretación, afirmando que «en todo este conjunto arquitectónico y escultórico no hay ni el mínimo indicio de algún culto dedicado a la familia imperial», aunque por otro lado, y curiosamente, sostiene que tal vez fuese el pórtico post scaenam del teatro, y no los Foros, el lugar elegido en Augusta Emerita para disponer los pedestales de los sacerdotes imperiales (TRILLMICH, 1993a: 122; 1996a: 183).

En los años centrales del siglo I d.C. culminaron las obras del teatro de Mérida mediante la construcción del pulpitum y la conclusión del frente escénico (DURÁN, 1994: 133-134), que fue ornamentado con un ciclo escultórico julioclaudio, del cual nos han llegado tres estatuas thoracatas, dos togados, una efigie masculina del tipo Hïftmantel (es decir, un emperador o un miembro de la casa imperial heroizado) y una cabeza de Agripina minor (TRILLMICH, 1993b: 114-116). Más tarde, en el año 130 de la fundación de la colonia (durante el principado de Trajano), se acometió una importante reforma en el graderío del teatro emeritense asociada al desarrollo del culto imperial: una inscripción atestigua la edificación de un sacrarium Larum et imaginum en la parte baja de la ima cavea. En este recinto sagrado se situaron seis pedestales de estatua con la inscripción Aug(usto) Sacr(um), un altar y varios fragmentos de relieves en los que aparecen apilamientos de armas (TRILLMICH, 19891990 y 1993b: 116-117).

Los numerosos hallazgos arquitectónicos, escultóricos y epigráficos acaecidos desde el siglo XVIII hasta nuestros días en las inmediaciones del actual Parador de Turismo, en torno a las calles Alvarado y Holguín, testimonian la existencia en dicha zona de un tercer Foro emeritense (ÁLVAREZ, 1982: 58-68; 1991b: 20-21; JIMÉ-

\footnotetext{
"Muy por el contrario, el reciente estudio de las técnicas edilicias empleadas (DURÁN, 1994: 133-134), así como de sus restos arquitectónicos, escultóricos y epigráficos demuestra que la terminación de las obras se produjo durante el principado de Claudio.
} 
NEZ, 1994: 247-248; BARRERA, 1994: 443-468), del cual formaron parte los vestigios documentados en el siglo pasado por Laborde -interpretados por J. M." Álvarez (1982: 60-63) como correspondientes a una basílica- un gran templo tetrástilo de época tiberiana cuyos monumentales restos han sido localizados en la calle Holguín (ÁLVAREZ, 1991b: 21; BARRERA, 1994: 443-447) y el llamado "Arco de Trajano», que estaría marcando un acceso a esta plaza. La cronología de la misma podría llevarse a la época fundacional de la colonia por su perfecta integración con la red de cardines y decumani del plan urbanístico original. No obstante, el templo detectado en la calle Holguín, dedicado al culto provincial (BARRERA, 1994: 448-459) pudo construirse, o cuando menos concluirse, en un momento posterior, debido a la utilización del mármol en su ornamentación (TRILLMICH, 1996a: 175).

La denominación de este tercer Foro de Augusta Emerita es motivo de controversia. Así, las inscripciones dedicadas a Tiberio y Domiciano y, sobre todo, aquellas otras erigidas en honor de Trajano y Constantino, además de vincular al templo citado con el culto imperial permitirían asignarle a esta plaza la titulación de Foro «provincial» (ÁLVAREZ, 1982: 64 y 68-69; 1991b: 20-21; BARRERA, 1994: 449452). Sin embargo, Trillmich (1993a: 117-122; 1996a: 175 y 182-183) ha optado por denominarlo Foro «norte», cuestionándose asimismo la vinculación del templo y del área forense con el culto provincial al no haberse hallado en dicho lugar ningún epígrafe dedicado por el concilium a los flamines o flaminicas de la Lusitania.

Los datos arqueológicos relativos al culto imperial en Colonia Patricia son en la actualidad algo más numerosos de lo que lo eran hace poco más de una década. Especial relevancia tienen en este sentido dos esculturas sedentes de plena época julioclaudia recuperadas en la calle San Álvaro n.. 4 (es decir, junto al ángulo SE de la plaza enlosada de las calles Cruz Conde-Góngora), representaciones de un emperador y una emperatriz asimilados a Júpiter y a Ceres o Juno, respectivamente (GARRIGUET, BARBADO y LÓPEZ, 1996; LÓPEZ y GARRIGUET, 1996). Por su proximidad, es probable que ambas estatuas mantuviesen alguna relación con los monumentales restos de un edificio público documentados en 1987 en el solar número 8 de la ya mencionada calle San Álvaro, en cuyo caso cabría plantear la hipotética conexión de dicho edificio forense con el culto dinástico (GARRIGUET, 1997). La magnífica estatua loricata colosal de la colección Tienda fue hallada también cerca del Foro de la colonia. Posee una cronología similar a la de las esculturas anteriores e igualmente un enorme sentido propagandístico de exaltación del poder imperial. Su interpretación como Rómulo con los spolia opima o como el Pater Eneas -a quien habrían acompañado su padre y su hijo-- ha llevado a Trillmich (1996a: 185-189) a pensar que en esta plaza cordobesa, como en el «Foro de mármol» de Mérida, se imitó la decoración escultórica del Foro de Augusto en Roma. Por otro lado, hemos de referirnos asimismo al pequeño fragmento de relieve descubierto en la ca- 
Ile Góngora (esquina con Braulio Laportilla) en el que aparece un camillus o asistente del sacerdote en los sacrificios. Dicha pieza debió ornamentar algún monumento sacro del Foro cordobés (GARRIGUET, 1996c).

Las excavaciones efectuadas durante los últimos años en el llamado «Patio romano» del Museo Arqueológico de Córdoba y las investigaciones desarrolladas a raíz de las mismas han permitido localizar el teatro de Colonia Patricia en la actual Plaza de Jerónimo Páez (VENTURA, 1996: 151-168; VENTURA, LEÓN y MÁRQUEZ, e.p.). Las obras del teatro cordobés -que, como los de otras muchas ciudades romanas, debió desempeñar un papel destacado en las ceremonias del culto dinástico (GROS, 1990)- se iniciaron en los primeros años del siglo I d.C. (VENTURA, 1996: 160; VENTURA, LEÓN y MÁRQUEZ, e.p.). La conexión del edificio con un complejo de plazas aterrazadas de carácter monumental (una de ellas quizás porticada) y su proximidad al Foro de Altos de Santa Ana ${ }^{2+}$ refuerzan esta impresión. Recientemente se ha propuesto, además, la posible existencia de un sacellum de culto imperial (VENTURA, 1996: 164), al cual pudieron pertenecer la columna con la inscripción Augusto Sacrum $(C I L$ II $/ 7,253)$ y una dedicación a la Fortuna Augusta (CIL II $=/ 7$ 225).

A mediados del siglo I d.C. concluyó la construcción del teatro, según se desprende de la información estratigráfica y del estudio de los elementos arquitectónicos que ornamentaban su fachada (VENTURA, 1996: 160; VENTURA, LEÓN y MÁRQUEZ, e.p.). De la historia posterior de este edificio muy poco es lo que puede decirse en estos instantes: por un lado, la cabeza-retrato de Antonino Pío (WEGNER, 1953: 77) hallada en un patio del Museo Arqueológico pudo formar parte de un ciclo estatuario de la dinastía antonina, como el presente en el teatro de Tarragona; por otro, la pérdida de su funcionalidad original debió acaecer muy a finales del siglo III o a principios del siglo IV d.C. (VENTURA, 1996: 162; VENTURA, LEÓN y MÁRQUEZ, e.p.).

Durante el principado de Claudio comenzó en Colonia Patricia la edificación del templo de la calle Claudio Marcelo y del recinto porticado que lo circundaba por tres de sus lados (Norte, Oeste y Sur). La cronología inicial de todo este conjunto monumental -muy posiblemente dedicado al culto imperial (¿provincial?)- ha sido establecida básicamente en función del material cerámico recuperado en el interior de la cella del templo (JIMÉNEZ, 1994: 245; 1996a: 141-143), pero también por el hallazgo en un muro tardío construido en la zona del pórtico oeste de un fragmento escultórico de época claudio-neroniana y correspondiente a una estatua colosal del tipo Hüftmantel (JIMÉNEZ, 1996b), utilizado frecuentemente para las representacio-

\&- Recordemos a este respecto las palabras de J. Ruiz de Arbulo (1993: 97) sobre la estrecha asociación existente en Tarragona entre el Foro bajo y el cercano teatro. 
nes de emperadores heroizados. No obstante, la terminación del templo y su área sagrada debió acontecer ya en época flavia.

Precisamente, la mayoría de los investigadores sitúan el establecimiento del culto provincial en la Bética (y por tanto en Colonia Patricia, sede del concilium provinciae) en los primeros años de la dinastía flavia (ETIENNE, 1974: 453-454; FISHWICK, 1991: 219-239 y 261-262). Basándose en el hallazgo de varios pedestales de estatua dedicados a flamines de la Bética, algunos autores han sostenido que en la calle Ángel de Saavedra y su entorno inmediato existió desde época de Vespasiano un auténtico Foro «provincial», a semejanza de lo que sucedió por aquellos mismos años en la gran plaza de la terraza superior de Tarraco (STYLOW, 1990: 274-279; JIMÉNEZ, 1994: 248; VENTURA 1996: 145-146). Sin entrar ahora en la polémica terminológica suscitada por esta interpretación (TRILLMICH, 1993a y 1996a: 181183) ${ }^{-5}$, queremos efectuar, sin embargo, algunas matizaciones a la misma:

$\left.1 .^{9}\right)$ En época tardoaugustea o tiberiana temprana ya existió en los Altos de Santa Ana un recinto forense, como prueban los datos estratigráficos obtenidos en la calle Ángel de Saavedra y en la Casa Carbonell (VENTURA, 1991: 261-262; LEÓN et alii, 163-165); así como los retratos de Livia y Tiberio (VICENT, 1984-1985: 60; 1989: 13-18; GARRIGUET, 1996a y 1996b), dos esculturas femeninas estantes (LÓPEZ, 1997: 112-114 y 129-131) o el pedestal de estatua dedicado al quaestor Lucio Axio Naso (CIL II $/ 7$, 273) hallados en esta zona.

2.") Hasta el momento presente son muy escasos (por no decir casi inexistentes) los testimonios arqueológicos de carácter monumental procedentes de Altos de Santa Ana que puedan fecharse con seguridad en época flavia o identificarse con edificios vinculados al culto imperial erigidos en esos mismos años ${ }^{26}$.

3. ${ }^{\circ}$ ) Los pedestales de los flamines provinciales localizados en el entorno de la calle Ángel de Saavedra se fechan entre finales del siglo II d.C. y el primer cuarto del siglo III d.C., aproximadamente. No hay, pues, ninguno de época de Vespasiano. El pedestal del flamen provincial más antiguo de los conocidos hasta ahora en Córdoba $\left(C I L \mathrm{II}^{2} / 7,282\right)$ tiene una datación domicianea o trajanea ${ }^{17} \mathrm{y}$, además, apareció en las proximidades del Foro de las calles Cruz Conde-Góngora, al igual que algunos otros mencionados mäs arriba.

A tenor de todos estas evidencias cabría plantearse, por tanto, cuándo se produjo realmente en Colonia Patricia la implantación del culto provincial y qué repercu-

"D. Fishwick ha manifestado su opinión a este respecto en un trabajo que verá próximamente la luz en el número 9 de la revista Anas.

$\therefore$ No obstante, A.U. Stylow (1990: 274), ha considerado segura la pertenencia de un capitel de dimensiones colosales hallado en la calle Jesús María (en realidad. Ángel de Saavedra) a un templo dedicado al culto imperial.

"Coincide, pues. en cronología con el más antiguo de la Bética documentado hasta este momento. el de $C$. $S c m$ pronius Speratus, fechado en el año 98 d.C. (FISHWICK. 1987: 219). 
siones urbanísticas tuvo este hecho en la capital de la Bética. Con respecto a la primera cuestión, los datos epigráficos disponibles apuntan hacia una cronología flavia avanzada (tal vez durante el principado de Domiciano). En cuanto a la segunda, es posible que los esfuerzos constructivos se centraran entonces, en contraste con lo acaecido en la primera mitad del siglo I d.C., en la realización de importantes obras de infraestructura ${ }^{2 \times}$, o en la culminación de los proyectos constructivos iniciados en los últimos años de la dinastía julioclaudia. Pero, de cualquier manera, hoy por hoy nada permite demostrar que el Foro de Altos de Santa Ana desempeñara a partir del principado de Vespasiano las funciones de un Foro «provincial»

Como quiera que fuese, junto a la posible pérdida de información causada por el fenómeno de la reutilización de soportes epigráficos o como consecuencia de otros avatares históricos, debemos tener en cuenta que la investigación arqueológica sobre la Córdoba romana se encuentra todavía en una fase inicial, y que, por tanto, la realización de futuros estudios sobre elementos arquitectónicos o escultóricos ya conocidos o los nuevos descubrimientos que en adelante se produzcan en el solar cordobés pueden hacer variar considerablemente estas apreciaciones. Recordemos, por ejemplo, que todavía existen dudas acerca de la ubicación y cronología de dos edificios tan importantes como el anfiteatro y el circo (VENTURA, 1996: 169-184).

\section{CONCLUSIONES}

Hasta aquí el análisis comparativo de la situación del culto imperial en cada una de las tres capitales de provincia hispanas. A modo de recapitulación nos resta ya, simplemente, enunciar las principales conclusiones que hemos extraído del mismo. Son las siguientes:

- En los momentos iniciales de este fenómeno político-religioso (entre finales del siglo I a.C. y los primeros años del siglo I d.C.), la ciudad de Tarraco desempeñó un marcado protagonismo dentro del ámbito de la Península Ibérica, erigiéndose en uno de los puntos de partida del culto imperial (colonial o municipal) desarrollado en Hispania. El ejemplo ofrecido por Tarraco a través de sus monumentos y de las monedas que los representaron fue imitado casi simultáneamente en otras ciudades peninsulares como Augusta Emerita, contribuyendo de esta manera a fomentar rápidamente la rivalidad entre ellas, lo cual tuvo, además, importantes consecuencias desde el punto de vista urbanístico. Aunque en Colonia Patricia faltan, al parecer, las monedas de carácter conmemorativo presentes en Tarraco o Augusta Emerita, sin embargo, algunos testimonios arqueológicos y epigráficos permiten situar también

¿En tiempos de Domiciano se dotó a la ciudad de un segundo acueducto -el Aqua Nova Domitiana Augusta-que vino a sumarse al ya existente desde época augustea (STYLOW, 1990: 269-270: VENTURA. 1996: 25-63). 
los inicios del culto imperial, colonial, en la capital de la Bética hacia la época tardoaugustea o en los primeros años del principado de Tiberio.

- El estado actual del conocimiento de los dos niveles básicos en los que se estructuró el culto imperial -el colonial o municipal y el provincial- es bastante desigual en las tres capitales hispanas. Ello se debe, en gran medida, a las diferentes vicisitudes vividas por cada una de estas ciudades y al diferente grado de desarrollo que han experimentado en ellas las investigaciones arqueológicas. Pero podría considerarse también una consecuencia de realidades económicas y sociales distintas en estas tres poblaciones hispanas durante los primeros siglos de nuestra Era, circunstancia que se habría reflejado con claridad en el culto imperial.

Así, en lo que se refiere a Tarragona, el elevado número de inscripciones halladas hasta la fecha en su solar y la particular distribución de las mismas por los distintos sectores de la ciudad han permitido establecer la evolución cronológica de ambos niveles y asignarle a las instituciones responsables de su mantenimiento (el ordo de la colonia y el poderoso concilio de la provincia) sus respectivos y bien delimitados espacios urbanos: el Foro bajo y el complejo arquitectónico de la terraza superior. En Mérida, por el contrario, estas mismas labores resultan algo más difíciles de realizar (y más aún si se pretende asemejar de manera forzada el caso emeritense al de Tarraco), debido a la escasez de epígrafes referidos tanto al culto colonial como al provincial y a su práctica ausencia en el contexto de las tres plazas identificadas en la ciudad. La situación en Córdoba podría calificarse de intermedia en lo referente a la cuantía de los datos conservados -bastante menor que en Tarragona, pero algo mayor que en Mérida-, aunque es considerablemente más compleja que las dos anteriores por lo que respecta a la delimitación de las competencias del ordo decurionum y del concilium provinciae sobre los diferentes sectores monumentales de la ciudad conocidos hasta la fecha.

- La diversa documentación existente hoy día permite afirmar que el culto colonial se instituyó en las tres capitales entre la época augustea y la julioclaudia temprana. En Tarraco y Colonia Patricia este culto colonial perduró claramente hasta las primeras décadas del siglo III d.C., aunque la mayor parte de los testimonios conocidos corresponden a la centuria anterior. En Augusta Emerita el epígrafe más moderno de un flamen de la colonia se fecha en la primera mitad del siglo II d.C., aunque la posible presencia de un templo consagrado a Antonino Pío permite pensar en su pervivencia, al menos, hasta finales de dicha centuria o principios de la siguiente.

En cuanto a los individuos encargados de su organización, cabe señalar que en Tarraco y Colonia Patricia junto a los consabidos flamines, flaminicas y seviri (presentes, asímismo, en Augusta Emerita aunque en menor cuantía) encontramos también actuando a los magistri Larum, cargo este último que, sin embargo, está ausente en la capital de la Lusitania y en toda esa provincia. A juzgar por estas evidencias, 
parece vislumbrarse cierto paralelismo entre las dos primeras ciudades con relación al aspecto organizativo del culto imperial colonial.

- Atendiendo a las fechas más antiguas que nos proporcionan las inscripciones dedicadas por los concilia a sus sacerdotes electos, la instauración efectiva del culto provincial en Augusta Emerita y en Tarraco habría acaecido durante los principados de Claudio y Vespasiano, respectivamente. En Colonia Patricia (y en el resto del territorio bético) los primeros flamines provinciales se fechan, de momento, entre los principados de Domiciano y Trajano.

El máximo desarrollo del culto provincial se alcanzó en Tarraco entre los últimos decenios del siglo I d.C. y el principado de Marco Aurelio. Pocos años más tarde cesó definitivamente la actividad del concilio provincial (desapareciendo desde entonces toda mención al mismo). En Colonia Patricia casi todas las inscripciones de los flamines provinciales" se sitúan cronológicamente entre finales del siglo II d.C. y mediados del III d.C., debido quizás en gran medida a la reutilización de epígrafes anteriores. No obstante, dicho reaprovechamiento puede considerarse también un hecho indicativo del auge que en esas fechas tan avanzadas mantenía todavía el concilio provincial bético. En indudable contraste con los casos tarraconense y patriciense, el reducido número de flamines y flaminicas provinciales conocidos en Augusta Emerita a través de la epigrafía oscila entre los años centrales del siglo I d.C. y la primera mitad de la centuria siguiente, sin que sepamos si el concilium lusitano pervivió en fecha posterior.

Al margen de las apreciaciones cronológicas, las titulaciones oficiales de los sacerdotes y sacerdotisas provinciales variaron también en las tres capitales de la Hispania romana. En Tarraco la denominación oficial, la mayoría de las veces abreviada, fue la de flamen Romae Divorum et Augustorum provinciae Hispaniae citerioris. Esta mención a la diosa Roma - presente también en la titulación de algunos flamines coloniales tarraconenses- se halla ausente, por el contrario, en los títulos de los flamines provinciales de la Lusitania y la Bética. En los primeros es corriente la escueta fórmula flamen/flaminica provinciae Lusitaniae, mientras que en los segundos el título más habitual es el de flamen Divorum Augustorum provinciae Baeticae.

En síntesis, los datos epigráficos y arqueológicos disponibles en las tres ciudades parecen indicar que en Tarraco el concilium provincial tuvo un peso y una autonomía frente al poder local indiscutiblemente mayores que en Augusta Emerita o en Colonia Patricia. Esta circunstancia tal vez pudiera explicarse por haber sido la Tarraconense la provincia más extensa y heterogénea de la Península Ibérica, con algunas amplias zonas - como la región minera del Noroeste- muy escasamente romanizadas, lo cual habría motivado, a su vez, la singular existencia de un culto impe-

$\because$ De momento. no hay atestiguada con seguridad ninguna flaminica provincial en la capital de la Bética. 
rial en el nivel de los conventus y la inclusión de la diosa Roma en la titulatura oficial de sus flamines y sacerdotes.

- En las tres capitales de provincia hispanas se ha podido constatar, tanto arqueológica como epigráficamente, la estrecha vinculación que mantuvieron sus principales espacios y edificios públicos (especialmente los foros y los teatros), con las ceremonias y festividades del culto imperial. Particularmente notoria resulta esta relación en Tarraco: basílica del Foro bajo, plaza de representación y recinto de culto de la terraza superior, teatro, anfiteatro y circo ofrecen evidencias al respecto; pero también se observa en Augusta Emerita, siendo segura en el «templo de Diana», en el templo de la calle Holguín y en dos sectores del teatro, y muy probable en el denominado Foro «de mármol». En Colonia Patricia prácticamente puede asegurarse la conexión del templo de la calle Claudio Marcelo con esta forma de culto político-religioso, al igual que en el caso del teatro (donde pudo existir un sacellum), aunque todavía faltan datos más concretos. Diversos testimonios arqueológicos permiten suponer la existencia de un edificio de culto imperial en la esquina SE del Foro de las calles Cruz Conde-Góngora, mientras que con relación al Foro de altos de Santa Ana la duda consiste únicamente en discernir qué tipo de culto (local o provincial) se practicó allí.

- Enlazando directamente con lo enunciado en el punto anterior, podría decirse que las grandes fases de monumentalización observadas en Tarraco, Augusta Emerita y Colonia Patricia vinieron motivadas, si no exclusivamente, sí al menos en gran medida por la implantación y el posterior desarrollo del culto imperial. La primera de esas fases se llevó a cabo entre los principados de Augusto y Tiberio (coincidiendo aproximadamente, en el caso particular de Mérida, con la propia fundación de la ciudad) y se caracterizó por el empleo predominante de las piedras locales -calizas en Tarraco y Colonia Patricia y granito en Augusta Emerita- como material constructivo, aunque ya comenzara a aparecer el mármol en la ornamentación de algunos edificios. Corresponden a este período el aedes Augusti situado en la basílica del Foro bajo de Tarragona, las plazas emeritenses estructuradas en torno al «templo de Diana» y al templo de la calle Holguín, el Foro cordobés de las calles Cruz Conde-Góngora y también el de Altos de Santa Ana; así como el sacellum del pórtico post scaenam del teatro de Augusta Emerita, o el inicio de las obras en el propio teatro de Mérida, en el de Córdoba y (quizás) en el de Tarragona.

A mediados del siglo I d.C. Augusta Emerita y Colonia Patricia experimentaron de forma paralela un nuevo e importante proceso de monumentalización caracterizado por la utilización generalizada del mármol. Dicho proceso supuso la aparición de una tercera plaza pública en ambas ciudades -el Foro de «mármol» en Mérida y el conjunto de templo y temenos de la calle Claudio Marcelo en Córdoba- y la imitación de la decoración arquitectónica y escultórica del Foro de Augusto en Roma en 
una de sus tres plazas. Se culminó también en esta época la edificación de los respectivos teatros de Augusta Emerita y Colonia Patricia. En el primero de ellos -y podemos suponer que también en el segundo- el frente escénico fue decorado con varias esculturas de la dinastía reinante. Aproximadamente por estos mismos años el Foro bajo y el teatro de Tarraco recibieron sendos ciclos estatuarios de la familia julioclaudia. Sin embargo, la segunda gran fase de monumentalización de la etapa imperial se produjo en la capital tarraconense durante la dinastía flavia. Fue entonces cuando se urbanizó la terraza alta de la ciudad mediante la construcción de un impresionante conjunto arquitectónico adscrito al concilio provincial y constituido sucesivamente por un recinto de culto, una gigantesca plaza de representación y un circo. La decoración arquitectónica del recinto sagrado refleja nuevamente la influencia del Forum Augustum de Roma, aunque con algunas variantes con relación al modelo original. En estos momentos concluyeron también las obras del teatro de $\mathrm{Ta}$ rraco. Mientras tanto, la actividad edilicia en Augusta Emerita y en Colonia Patricia se limitó tal vez a la conclusión de los importantes proyectos iniciados en años anteriores, aunque en la capital de la Bética sabemos que se construyó asimismo un nuevo acueducto (el segundo de la ciudad) durante el principado de Domiciano.

La intensa monumentalización arquitectónica y escultórica que conocieron las tres capitales hispanas a lo largo de todo el siglo I d.C. contrasta enormemente con la relativa «calma» constructiva detectada en aquellas durante la centuria siguiente a través de la documentación arqueológica. Así, en lo que hace referencia a Tarraco, debemos destacar tan sólo la erección del anfiteatro hacia la primera mitad del siglo II d.C. y bajo el patrocinio de un flamen provincial, y la ubicación de sendos ciclos icónicos de la dinastía antonina en el teatro y el Foro bajo. Por otro lado, en época del emperador Trajano el graderío del teatro de Augusta Emerita acogió un sacrarium dedicado al culto imperial. La realidad arqueológica de Colonia Patricia durante el siglo II d.C. resulta todavía más desconocida que las de Tarragona o Mérida. No obstante, es posible que el teatro de la ciudad recibiera un programa de ornamentación escultórica en tiempos de la dinastía antonina. Del Foro colonial y de aquel otro situado en los Altos de Santa Ana proceden también algunos restos escultóricos de carácter oficial y adscritos a esta época.

\section{BIBLIOGRAFÍA}

ALFÖLDY, G. (1973): Flamines Provinciae Hispaniae Citerioris. Anejos de AEA VI. Madrid.

ALFÖLDY, G. (1975): Die römischen Inschriften von Tarraco. Berlín.

ÁLVAREZ MARTínEZ, J. M." (1982): «El Foro de Augusta Emerita», en Homenaje a Sáenz de Buruaga. Madrid, pp. 53-68. 
ÁLVAREZ MARTÍNEZ, J. M.ำ (1991a): «El templo de Diana», en Templos Romanos de Hispania. Cuadernos de Arquitectura Romana 1. Murcia, pp. 83-93.

ÁLVAREZ MARTÍNEZ, J. M." (1991b): «La ciudad romana de Mérida», en Cuadernos de Arte Español 6. Madrid.

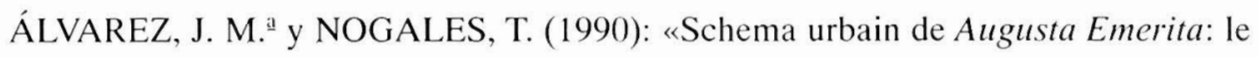
portique du Forum", en Akten des XIII Internationalen Kongresses für Klassische Archäologie (Berlín, 1988). Mainz am Rhein, pp. 336-338.

ÁLVAREZ SÁENZ DE BURUAGA, J. (1982): «Observaciones sobre el teatro romano de Mérida», en El teatro en la Hispania romana. Badajoz, pp. 303-316.

APARICIO, L. y VENTURA, A. (1996): «Flamen provincial documentado en Córdoba y nuevos datos sobre el Foro de la Colonia Patricia», AAC 7, pp. 251-264.

BARRERA, J. L. de la (1994): La decoración arquitectónica de los Foros de Augusta Emerita. Tesis Doctoral inédita. Cáceres.

BARRERA, J. L. de la y TRILLMICH, W. (1996): «Eine Wiederholung der AeneasGruppe vom Forum Augustum samt iher Inschrift in Mérida (Spanien)», RM 103, pp. 119-138.

BLANCO FREIJEIRO, A. (1982): «Miscelánea arqueológica emeritense», en Homenaje a Sáenz de Buruaga. Madrid, pp. 23-32.

BOSCHUNG, D. (1990): «Die Präsenz des Kaiserhauses im öffentlichen Bereich», en W. Trillmich y P. Zanker (Eds.): Stadtbild und Ideologie. Die Monumentalisierung hispanischer Städte zwischen Republik und Kaiserzeit (Madrid, 1987). München, pp. 391-400.

CERRILLO MARTÍN DE CÁCERES, E. (1995): «Augustus y Augusta Emerita», Forum de Arqueología 1, pp. 64-67.

CHAVES TRISTÁN, F. (1977): La Córdoba hispano-romana y sus monedas. Sevilla.

DURÁN CABELLO, R. M. (1994): «Elementos para la historia de Mérida a través del análisis arquitectónico: el caso del teatro», en La ciudad en el mundo romano. Actas del XIV Congreso Internacional de Arqueología Clásica (Tarragona, 1993). Tarragona, vol. 2, pp. 132-135.

ETIENNE, R. (1974): Le culte impérial dans la Péninsule Ibérique d'Auguste a Dioclétien. París.

ETIENNE, R. (1990): «Le culte impérial, vecteur de la hiérarchisation urbaine», en Les villes de Lusitanie romaine (Talence, 1988). París, pp. 215-231.

FISHWICK, D. (1987): The imperial cult in the Latin West. Leiden. Tomos I.1 y I.2. FISHWICK, D. (1991): The imperial cult in the Latin West. Leiden. Tomo II.1. 
FISHWICK, D. (1996): «Four temples at Tarraco», en A. Small (Ed.): Subject and Ruler: The cult of the ruling power in Classical Antiquity. Supplementary Series of JRA 17. Michigan, pp. 165-184.

GARRIGUET MATA, J. A. (1996a): «Retrato de la emperatriz Livia», en D. Vaquerizo (Ed.): Córdoba en tiempos de Séneca. Córdoba, pp. 50-51.

GARRIGUET MATA, J. A. (1996b): «Retrato del emperador Tiberio», en D. Vaquerizo (Ed.): Córdoba en tiempos de Séneca. Córdoba, pp. 52-53.

GARRIGUET MATA, J. A. (1996c): «Relieve con oferente», en D. Vaquerizo (Ed.): Córdoba en tiempos de Séneca. Córdoba, pp. 62-63.

GARRIGUET MATA, J. A. (1997): «Un posible edificio de culto imperial en la esquina SE del Foro de Córdoba», Antiquitas 8, pp. 73-80.

GARRIGUET, J. A., BARBADO, T. y LÓPEZ, I. (1996): «Estatua masculina sedente» en $D$. Vaquerizo (ed.): Córdoba en tiempos de Séneca. Córdoba, pp. 5859.

GIMENO, J. (1994): «Plinio, Nat. Hist. III, 3, 21: reflexiones acerca de la capitalidad de Hispania Citerior», Latomus 53.1, pp. 39-79.

GROS, P. (1990): «Théâtre et culte impérial en Gaule Narbonnaise et dans la Péninsule Ibérique», en W. Trillmich y P. Zanker (Eds.): Stadtbild und Ideologie. Die Monumentalisierung hispanischer Städte zwischen Republik und Kaiserzeit (Madrid, 1987). München, pp. 381-390.

GÜELL, M. et alii (1993): «La restitución arquitectónica de la Plaza de Representación (el denominado «Foro Provincial»)», en Els monuments provincials de Tàrraco. Noves aportacions al seu coneixement. Documents d'Arqueologia Clàssica 1 . Tarragona, pp. 157-190.

JIMÉNEZ SALVADOR, J. L. (1994): «El templo romano de la calle Claudio Marcelo en Córdoba y su importancia dentro del programa monumental de Colonia Patricia durante el Alto Imperio», en La ciudad en el mundo romano. Actas del XIV Congreso Internacional de Arqueología Clásica (Tarragona, 1993). Tarragona, vol. 1, pp. 245-251.

JIMÉNEZ SALVADOR, J. L. (1996a): «El templo romano de la calle Claudio Marcelo en Córdoba: aspectos cronológicos, urbanísticos y funcionales», en P. León (Ed.): Colonia Patricia Corduba: una reflexión arqueológica (Córdoba, 1993). Sevilla, pp. 129-153.

JIMÉNEZ SALVADOR, J. L. (1996b): «Notas sobre un fragmento escultórico procedente del recinto presidido por el templo romano de la calle Claudio Marcelo en Córdoba», en Actas de la II Reunión sobre escultura romana en Hispania (Tarragona, 1995). Tarragona, pp. 49-57.

KOPPEL, E. (1985): Die römischen Skulpturen von Tarraco. Berlín. 
KOPPEL, E. (e.p.): «Dos nuevos retratos julio-claudios de Tarragona», en Actas de la III Reunión de escultura romana en Hispania (Córdoba, 1997).

KOPPEL, E. y MACÍAS, J. M. (1995): «Nuevos hallazgos escultóricos en la ciudad de Tarragona», Revista de Arqueología 175, pp. 62-64.

LEÓN, P. et alii (1994): «Informe sucinto de resultados de la excavación arqueológica sistemática en el solar de la casa Carbonell (Córdoba), 1991. Proyecto: Análisis arqueológico de la Córdoba romana», Anuario Arqueológico de Andalucía (1991). Tomo II, Sevilla, pp. 158-171.

LÓPEZ LÓPEZ, I. (1997): Estatuas togadas y estatuas femeninas vestidas de colecciones cordobesas. Tesis Doctoral inédita. Universidad de Córdoba.

LÓPEZ, I. y GARRIGUET, J. A. (1996): «Estatua femenina sedente», en D. Vaquerizo (ed.): Córdoba en tiempos de Séneca. Córdoba, pp. 60-61.

MAR, R. (1993): «El recinto de culto imperial de Tarraco y la arquitectura flavia», en Els monuments provincials de Tàrraco. Noves aportacions al seu coneixement. Documents d'Arqueologia Clàssica 1. Tarragona, pp. 107-156.

MAR, R. y RUIZ DE ARBULO, J. (1987): «La Basílica de la Colonia Tarraco. Una nueva interpretación del llamado Foro Bajo de Tarragona», en Los Foros romanos de la provincias occidentales (Valencia, 1986). Madrid, pp. 31-44.

MAR, R. y RUIZ DE ARBULO, J. (1988): «Tribunal/Aedes Augusti. Algunos ejemplos hispanos de la introducción del culto imperial en las Basílicas forenses», en Estudios sobre la Tabula Siarensis. Anejos de AEspA IX. Madrid, pp. 276-306.

MAR, R., ROCA, M. y RUIZ DE ARBULO, J. (1993): «El teatro romano de Tarragona. Un problema pendiente», en Teatros Romanos de Hispania. Cuadernos de Arquitectura Romana 2. Murcia, pp. 11-23.

NOGALES BASARRATE, T. (1989-1990): «Dos retratos femeninos del «templo de Diana» de Mérida", Anas 2-3, pp. 183-194.

NOGALES BASARRATE, T. (1996): «Programas iconográficos del Foro de Mérida: el templo de Diana», en Actas de la II Reunión sobre escultura romana en Hispania (Tarragona, 1995). Tarragona, pp. 115-134.

NOGALES BASARRATE, T. (e.p.): «Un altar en el Foro de Augusta Emerita», en Actas de la III Reunión de escultura romana en Hispania (Córdoba, 1997).

ORIA, M. y MORA DE LOS REYES, M. (1991-1992): «La arquitectura religiosa de la Bética a través de la epigrafía», Anas 4-5, pp. 115-135.

PENSABENE, P. (1993): «La decorazione architettonica dei monumenti provinciali di Tarraco", en Els monuments provincials de Tàrraco. Noves aportacions al seu coneixement. Documents d'Arqueologia Clàssica 1. Tarragona, pp. 33-105.

RODRÍGUEZ NEILA, J. F. (1978): «Sobre los procesos de la Bética contra los gobernadores romanos», en Actas del I Congreso de Historia de Andalucía (Córdoba, 1976). Córdoba, tomo I, pp. 231-238. 
RUIZ DE ARBULO BAYONA, J. (1990): «El Foro de Tarraco», Cypsela VIII, pp. 119-138.

RUIZ DE ARBULO BAYONA, J. (1993): «Edificios públicos, poder imperial y evolución de las élites urbanas en Tarraco (s. II-IV d.C.)", en Ciudad y comunidad civica en Hispania (siglos II y III d.C.) (Madrid, 1990). Madrid, pp. 93-113.

SAQUETE, J.C. y MÁRQUEZ, J. (1997): «Un fragmento de pedestal descubierto en Mérida: a propósito del Foro y de la colonia Augusta Emerita en los siglos IIIIV», Mérida, ciudad y Patrimonio 1, pp. 45-53.

STYLOW, A. (1990): «Apuntes sobre el urbanismo de la Corduba romana», en W. Trillmich y P. Zanker (Eds.): Stadtbild und Ideologie. Die Monumentalisierung hispanischer Städte zwischen Republik und Kaiserzeit (Madrid, 1987). München, pp. 259-282.

TED’A (1989): «El Foro provincial de Tarraco: un complejo arquitectónico de época flavia», AEspA 62, pp. 141-191.

TRILLMICH, W. (1989-1990): «Un sacrarium del culto imperial en el teatro de Mérida», Anas 2-3, pp. 87-102.

TRILLMICH, W. (1993a): ««Foro provincial» und «Foro municipal» in den Hauptstädten der drei hispanischen Provinzen: eine Fiktion», en Ciudad y comunidad cívica en Hispania (siglos II y III d.C.) (Madrid 1990). Madrid, pp. 115-124.

TRILLMICH, W. (1993b): «Novedades en torno al programa iconográfico del teatro romano de Mérida», en Actas de la I Reunión sobre escultura romana en Hispania (Mérida, 1992). Madrid, pp. 113-123.

TRILLMICH, W. (1995): «Gestalt und Ausstattung des «Marmorforums» in Mérida», MM 36, pp. 269-291.

TRILlMICH, W. (1996a): «Los tres foros de Augusta Emerita y el caso de Corduba», en P. León (Ed.): Colonia Patricia Corduba: una reflexión arqueológica (Córdoba, 1993). Sevilla, pp. 175-195.

TRILLMICH, W. (1996b): «Reflejos del programa estatuario del Forum Augustum en Mérida», en Actas de la II Reunión sobre escultura romana en Hispania (Tarragona, 1995). Tarragona, pp. 95-108.

VELÁZQUEZ JIMÉNEZ, A. (1988): «Una Helvia, flaminica en Augusta Emerita», Anas 1, pp. 125-132.

VENTURA VILLANUEVA, A. (1991): «Resultados del seguimiento arqueológico en el solar de C/ Angel de Saavedra n. 10, Córdoba», AAC 2, pp. 253-290.

VENTURA VILLANUEVA, A. (1996): El abastecimiento de agua a la Córdoba romana. II. Acueductos, ciclo de distribución y urbanismo. Córdoba. 
VENTURA, A., LEÓn, P. y MÁRQUEZ, C. (e.p.): «Roman Corduba in the light of new discoveries», en S.J. Keay (Ed.): Roman Baetica. Supplementary series of the JRA. Michigan.

VENTURA, A. et alii (1996): «Análisis arqueológico de la Córdoba romana: resultados e hipótesis de la investigación», en P. León (Ed.): Colonia Patricia Corduba: una reflexión arqueológica (Córdoba, 1993). Sevilla, pp. 87-118.

VICENT ZARAGOZA, A. M." (1984-1985): «Lote de esculturas romanas de los Altos de Santa Ana», Corduba Archaeologica 15, pp. 55-62.

VICENT ZARAGOZA, A. M." (1989): Retratos romanos femeninos del Museo Arqueológico de Córdoba. Discurso de ingreso en la Real Academia de Ciencias, Bellas Letras y Nobles Artes de Córdoba. Córdoba.

WEGNER, M. (1953): «Römische Herrcherbildnisse des zweiten Jahrhunderts in Spanien», AEspA 26, 1953, pp. 67-90.

ZANKER, P. (1992): Augusto y el poder de las imágenes. Madrid.

\section{Post scriptum:}

En el tiempo transcurrido entre la entrega del texto original de este trabajo y su publicación definitiva se han producido, lógicamente, ciertos avances en lo que respecta a la investigación epigráfica y arqueológica del culto imperial en las capitales provinciales hispanas. En estas breves líneas queremos señalar de manera escueta algunos de tales avances, habida cuenta el carácter compilatorio de nuestro artículo. Así, destacamos, por un lado, el estudio de J. Edmondson (1997): «Two dedications to Divus Augustus and Diva Augusta from Augusta Emerita and the early development of the imperial cult in Lusitania re-examinated» $M M 38$, pp. 89-105, que ha arrojado bastante luz sobre la verdadera titulación de los flamines provinciales de la Lusitania en época de Claudio; no menos interés posee el reciente descubrimiento de, al parecer, los restos del circo de Córdoba -al menos el de época altoimperial-en el sector de la ciudad comprendido entre la iglesia de San Pablo y la «manzana de Orive», muy cerca del templo de la calle Claudio Marcelo. La posible conexión de este edificio religioso y de la plaza que lo rodeaba con dicho circo cuenta con el paralelo del gran complejo provincial de la parte alta de Tarragona y obliga a preguntarse, por tanto, acerca de la modalidad y la cronología del culto que se desarrolló en esta zona del solar patriciense. Las noticias relativas a este importante hallazgo pueden encontrarse en Murillo, J. F. et alii (1997): «Córdoba: 300-1236 d.C., un milenio de transformaciones urbanas», en Urbanism in Medieval Europe. Papers of the "Medieval Europe Brugge 1997» Conference. Tomo I, pp. 47-60, en concreto la página 49. También en Diario Córdoba, 24 de febrero de 1998, p. 3. 